ISSN Cetak : 2087-0434

E-ISSN : :2599-0810

\title{
ANALISIS KINERJA KEUANGAN BANK UMUM SYARIAH
}

\author{
Roro Diyah Puspita Sari ${ }^{1)}$, Axel Giovanni ${ }^{2)}$ \\ ${ }^{1,2)}$ Fakultas Ekonomi, Universitas Tidar \\ Email: rorodiyah00@gmail.com \\ Email: axelgiovanni@untidar.ac.id
}

\begin{abstract}
Abstrak
Penelitian ini bertujuan untuk menganalisis kinerja keuangan perbankan syariah di Indonesia yang terdaftar di Otoritas Jasa Keuangan periode 2016-2020. Penelitian ini merupakan jenis penelitian kuantitatif dengan metode pendekatan studi deskriptif. Data sekunder diperoleh dari situs web Otoritas Jasa Keuangan dan situs web masing-masing bank terkait yang terdaftar di Otoritas Jasa Keuangan. Populasi dalam penelitian ini adalah 14 perusahaan dengan 8 sampel perusahaan perbankan umum syariah Indonesia yang terdaftar di Otoritas Jasa Keuangan. Sampel dalam penelitian ini diambil dengan menggunakan metode purposive sampling dengan kriteria perusahaan: 1. Berdiri lebih dari 10 tahun 2. Memiliki laporan keuangan lengkap tahun 2016-2020. Penelitian ini menggunakan alat analisis nilai minimum, nilai maksimum, rata-rata (mean) dan standar deviasi yang diolah menggunakan aplikasi SPSS. Data yang telah diolah kemudian dibandingkan dengan studi kelayakan kinerja perbankan syariah berdasarkan ketentuan Bank Indonesia. Penelitian ini melibatkan rasio Capital Adequacy Ratio (CAR), Return On Assets (ROA), Return On Equity (ROE), Operating Costs of Operating Income (BOPO), Net Interest Margin (NIM), Loan to Deposit (LDR), dan Non Performing Loan (NPL) dalam menilai kinerja keuangan. Hasil penelitian membuktikan bahwa Bank Umum Syariah periode 2016-2020 memiliki kinerja keuangan yang BAIK. Hasil penelitian dapat memberikan gambaran perbankan syariah bagi masyarakat, investor, dan debitur dalam memilih bank syariah sebagai media penyimpanan, penyetoran, dan peminjaman dana.
\end{abstract}

Kata Kunci : Kinerja Keuangan, Bank Syariah, Rasio Keuangan

\section{PENDAHULUAN}

Bank merupakan salah satu lembaga penting dalam perekonomian suatu negara. Bank berperan dalam melakukan penghimpunan dana dari masyarakat dalam bentuk simpanan dan menyalurkan dana yang dihimpun kepada masyarakat melalui kredit atau bentuk lain. Di Indonesia sendiri terdapat dua jenis perbankan, yaitu perbankan konvensional dan perbankan Syariah. Bank konvensional merupakan bank yang menjalankan kegiatan usahanya secara konvensional dimana dalam kegiatan tersebut memberikan jasa dalam pembayaran. Sedangkan bank syariah adalah bank yang menjalankan kegiatan usahanya berdasarkan prinsip syariah dimana dalam 
ISSN Cetak : 2087-0434

E-ISSN : $\quad$ 2599-0810

kegiatannya memberikan jasa dalam pembayaran. Bank Syariah di Indonesia semakin mengalami peningkatan sejak diperkenalkan secara resmi kepada masyarakat pada tahun 1992. Perkembangan industri keuangan syariah secara informal sudah dimulai sebelum adanya kerangka hukum formal sebagai landasan operasional perbankan di Indonesia. Beberapa badan usaha pembiayaan non bank sudah didirikan sebelum tahun 1992 dan menerapkan konsep bagi hasil dalam kegiatannya. Hal ini menunjukkan kebutuhan masyarakat akan hadirnya institusi keuangan yang dapat memberikan jasa keuangan sesuai dengan prinsip syariah (Vivin \& Wahono, 2017)

Di Indonesia pengembangan sistem perbankan Syariah dilakukan dalam kerangka dual banking system atau biasa disebut system perbankan ganda dalam kerangka Arsitektur Perbankan Indonesia (API). Bank syariah dalam kinerjanya dalam perbankan berbeda dengan bank konvensional. Bank Syariah menerapkan system akad yang mempunyai konsekuensi ukhrawi dan duniawi sesuai dengan hukum islam. Bank Syariah menerapkan prinsip bagi hasil yang memungkinkan nasabah mengawasi langsung kinerja bank Syariah melalui monitoring dari jumlah bagi hasil yang didapatkan. Proses bagi hasil dalam perbankan Syariah disesuaikan dengan hasil atau keuntungan dalam pengelolaan dana nasabah. Bagi hasil dengan nominal besar menunjukkan jumlah keuntungan bank besar. Begitu pula sebaliknya. Bagi hasil dengan nominal kecil menunjukkan keuntungan bank kecil dan merupakan indikator kemerosotan pengelolaan dalam perbankan syariah (Vivin \& Wahono, 2017).

Konsep ekonomi perbankan syariah lebih tahan krisis ekonomi global. Perbankan syariah mampu bertahan dan tidak terpengaruh krisis ekonomi. Pada tahun 1998 di Indonesia terjadi krisis ekonomi yang menyebabkan banyaknya bank konvensional mengalami kemunduran dan banyak dilikuidasi karena kegagalan dalam sistem bunganya. Pada tahun 2008 krisis ekonomi kembali terjadi yang berdampak pada perlambatan laju pertumbuhan ekonomi nasional. Namun, bank syariah justru mengalami penambahan jaringan pelayanan bank sebanyak 45 kantor (Sovia et al., 2016). Hal tersebut membuktikan bahwa perbankan syariah mampu bertahan di tengah krisis ekonomi dibandingkan dengan bank konvensional. Perbankan syariah saat ini semakin diminati masyarakat. Hal tersebut terlihat dari 
ISSN Cetak : :2087-0434

E-ISSN : :2599-0810

semakin meningkatnya layanan perbankan di Indonesia. Bank syariah di Indonesia dalam rentang waktu yang relatif singkat, telah memperlihatkan kemajuan yang cukup besar dan semakin memperlihatkan eksistensinya dalam sistem perekonomian nasional. Bank berdasarkan prinsip syariah seperti halnya pada bank konvensional, mempunyai fungsi sebagai lembaga intermediasi, dimana bank Syariah sebagai lembaga perantara untuk menyalurkan dana dari masyarakat yang kelebihan dana ke masyarakat yang membutuhkan dana guna meningkatkan kesejahteraan. Sistem syariah pada perbankan menawarkan keadilan, akuntabilitas, transparansi dan saling percaya antara para pelaku ekonomi. Sistem ekonomi dunia saat ini di dominasi oleh segelintir pemilik modal, dan parakapitalis yang memiliki pengaruh yang luar biasa dalam perekonomian. Sistem syariah berupaya untuk menerapkan sistem yang seadil-adilnya terhadap nasabah.

Saat ini tiga perbankan Syariah di Indonesia per-Februari 2021 melakukan merger atau bergabung menjadi satu perusahaan bernama Bank Syariah Indonesia. Bank Syariah Indonesia merupakan gabungan dari tiga bank Syariah besar di Indonesia yaitu Bank Rakyat Indonesia Syariah, Bank Negara Indonesia Syariah, dan Bank Mandiri Syariah. Ketiga bank Syariah tersebut bergabung menjadi bank Syariah terbesar di Indonesia saat ini. Ini menunjukkan bahwa Perbankan Syariah semakin eksis dan diminati masyarakat. Namun, hal ini menjadi tantangan tersendiri bagi perbankan syariah di Indonesia. Semakin banyaknya perbankan syariah yang bermunculan mendorong terjadinya persaingan antar bank syariah di Indonesia. Persaingan ini membuat bank-bank syariah di Indonesia harus terus meningkatkan kinerjanya.

Kinerja keuangan adalah gambaran kerja suatu perusahaan dengan melihat hasil laporan keuangan dari perusahaan tertentu pada periode tertentu dengan memperhatikan variable-variabel terkait. Kinerja keuangan perbankan merupakan gambaran hasil kinerja perbankan pada periode tertentu. Gambaran ini biasanya tersaji dalam laporan keuangan tahunan yang diterbitkan oleh perbankan. Dalam laporan keuangan tersaji berbagai variable pengukuran kinerja terutama biasanya ukuran kinerja keuangan perbankan adalah dari rasio keuangannya. Kinerja keuangan penting bagi perbankan, stakeholder, dan investor untuk memberikan gambaran seberapa baik kinerja suatu perbankan tertentu. Bagi perbankan terkait 
ISSN Cetak : 2087-0434

E-ISSN : :2599-0810

analisis kinerja ini dapat menjadi bahan evaluasi kinerja kedepan, bagi stakeholder untuk menentukan keputusan yang akan diambil untuk meningkatkan kinerja perbankan kedepan agar mampu bersaing dengan perbankan lainnya. Bagi investor kinerja keuangan penting untuk mengukur dan menentukan pengambilan keputusan investasi.

\section{Tabel 1}

\section{Rangkuman Kinerja Keuangan Perbankan Syariah di Indonesia}

\begin{tabular}{rlllllll}
\hline No. & Rasio Keuangan & $\mathbf{2 0 1 6}$ & $\mathbf{2 0 1 7}$ & $\mathbf{2 0 1 8}$ & $\mathbf{2 0 1 9}$ & $\mathbf{2 0 2 0}$ & Mean \\
\hline 1. & CAR & 16,63 & 17,91 & 20,39 & 20,59 & 21,64 & 19,432 \\
2. & ROA & 0,63 & 0,63 & 1,28 & 1,73 & 1,40 & 1,134 \\
3. & FDR & 85,99 & 79,61 & 78,53 & 77,91 & 76,36 & 79,68 \\
4. & BOPO & 96,22 & 94,91 & 89,18 & 84,45 & 85,55 & 90,062 \\
5. & NOM & 0,68 & 0,67 & 1,42 & 1,92 & 1,46 & 1,23 \\
\hline
\end{tabular}

Sumber: Data Statistik Bank Umum Syariah Otoritas Jasa Keuangan

Keterangan:

CAR : Capital Adequacy Ratio, ROA : Return On Asset, BOPO : Biaya Operasional per Pendapatan Operasional, REO : Rasio Efisiensi Operasional, NIM : Net Interest Margin, NOM : Net Operating Margin, LDR : Loan to Deposit Ratio, FDR : Financing to Deposit Ratio

Tabel 1. menunjukkan kinerja keuangan perbankan syariah periode 20162020. Secara keseluruhan dari tahun ke tahun CAR perbankan syariah mengalami kenaikan, ROA mengalami fluktuasi, LDR mengalami tren penurunan, BOPO cenderung turun, dan NOM mengalami fluktuasi. Secara keseluruhan kinerja keuangan perbankan syariah telah memenuhi standar yang di tetapkan oleh Bank Indonesia. CAR yang lebih dari 8\%. ROA lebih dari 1,5\% pada tahun 2019 sedangkan pada 2016, 2017, 2018, dan 2020 belum memenuhi standar Bank Indonesia. LDR pada tahun 2016 memenuhi standar Bank Indonesia dimana LDR antara 85\%-110\% sedangkan LDR bank syariah pada 2017-2020 masih berada dibawah standar Bank Indonesia. Nilai BOPO pada tahun 2019 menunjukkan tahun paling baik karena semakin kecil nilai BOPO maka semakin efisien pula kinerja suatu perbankan. Nilai NIM pada perbankan syariah sudah memenuhi syarat karena berada dibawah $5,5 \%$. 
ISSN Cetak : 2087-0434

E-ISSN : :2599-0810

Data ringkasan dari Otoritas Jasa Keuangan digunakan sebagai dasar pada penelitian ini. Namun, penelitian ini berusaha mengukur kinerja keuangan perbankan syariah yang terdaftar di OJK menggunakan kriteria tertentu yang telah ditetapkan dan analisis yang dilakukan menggunakn lebih banyak rasio keuangan untuk mengukur kesehatan perbankan syariah di Indonesia terdaftar di OJK. Penelitian ini akan menganalisis seberapa baik kinerja keuangan perbankan syariah terdaftar di OJK pada periode tahun 2016-2020 dengan memperhatikan detail laporan keuangan perbankan terkait.

\section{METODE PENELITIAN}

Penelitian ini merupakan jenis penelitian kuantitatif dengan metode pendekatan studi deskriptif. Data sekunder didapatkan dari website Otoritas jasa Keuangan dan website masing-masing perbankan terkait yang terdaftar di Otoritas Jasa Keuangan. Populasi pada penelitian ini adalah 14 perusahaan dengan 8 sampel perusahaan perbankan umum syariah Indonesia yang terdaftar di Otoritas Jasa Keuangan. Sampel pada penelitian ini diambil menggunakan metode purposive sampling dengan kriteria perusahaan: 1. Berdiri lebih dari 10 tahun 2. Memiliki laporan keuangan yang lengkap dari 2016-2020.

Perbankan syariah yang berdiri lebih dari sepuluh tahun dianggap sudah mempunyai sistem yang baik dan tidak berubah-ubah karena mereka tidak dalam masa perintisan perusahaan dimana mudah mengalami perubahan kebijakan tertentu apabila dirasa tidak sesuai. Kinerja keuangan perbankan syariah yang dianalisis pada penelitian ini mengandalkan laporan keuangan bank syariah yang terdaftar di OJK. Oleh karenanya laporan keuangan yang lengkap menjadi tolok ukur kriteria sampel di penelitian ini. Penelitian ini menggunakan alat analisis nilai minimum, nilai maximum, rata-rata (mean) dan standar deviasi yang diolah menggunakan aplikasi SPSS. Data yang sudah diolah kemudian dibandingkan dengan studi kelayakan kinerja perbankan syariah berdasarkan peraturan Bank Indonesia. Penelitian ini melibatkan rasio Capital Adequacy Ratio (CAR), Return On Asset (ROA), Return On Equity (ROE), Biaya Operasional Pendapatan Operasional (BOPO), Net Interest Margin (NIM), Loan to Deposite (LDR), dan Non Performing Loan (NPL) dalam 
ISSN Cetak : 2087-0434

E-ISSN : $\quad$ 2599-0810

menilai kinerja keuangan perbankan syariah yang terdaftar di OJK dengan melihat laporan tahunan dari tahun 2016-2020 pada masing-masing perbankan sampel.

Penelitian ini melibatkan rasio Capital Adequacy Ratio (CAR), Return On Asset (ROA), Return On Equity (ROE), Biaya Operasional Pendapatan Operasional (BOPO), Net Interest Margin (NIM), Loan to Deposite (LDR), dan Non Performing Loan (NPL) sebagai variabel analisis kinerja perbankan syariah. Tujuh variabel yang digunakan tersebut kemudian diolah dan dianalisis menggunakan kriteria penilaian rasio perbankan sesuai dengan peraturan Bank Indonesia.

\section{CAR (Capital Adequacy Ratio)}

Capital Adequacy Ratio, merupakan penilaian terhadap aspek permodalan suatu bank guna mengetahui kecukupan modal bank dalam mendukung kegiatan bank secara efektif dan efisien. Aspek indikator permodalan disesuaikan berdasarkan KPMM (Kewajiban Penyediaan Modal Minimum) (Sovia et al., 2016). CAR dapat dihitung menggunakan rumus matematis sebagai berikut:

$$
C A R=\frac{\text { Modal Inti }- \text { Modal Pelengkap }}{A T M R}
$$

Tabel 2

Kriteria Penilaian CAR

\begin{tabular}{cc}
\hline Nilai & Predikat \\
\hline CAR $\geq 12 \%$ & Sangat Baik \\
$9 \% \leq$ CAR $<12 \%$ & Baik \\
$8 \% \leq$ CAR $<9 \%$ & Cukup Baik \\
$6 \% \leq \mathrm{CAR}<8 \%$ & Kurang Baik \\
CAR $\leq 6 \%$ & Tidak Baik
\end{tabular}

Sumber: Kodifikasi Penilaian Bank Indonesia

2. ROA (Return On Asset)

Return on Asset, merupakan kemampuan perusahaan dalam menghasilkan laba dengan memanfaatkan seluruh modal. ROA dapat dihitung menggunakan rumus matematis sebagai berikut:

$$
\text { ROA }=\frac{\text { laba bersih }}{\text { total aset }} \times 100 \%
$$


ISSN Cetak : 2087-0434

E-ISSN : :2599-0810

Tabel 3

Kriteria Penilaian ROA

\begin{tabular}{cc}
\hline Nilai & Predikat \\
\hline ROA $\geq 1,5 \%$ & Sangat Baik \\
$1,25 \% \leq \mathrm{ROA}<1,5 \%$ & Baik \\
$0,5 \% \leq \mathrm{ROA}<1,25 \%$ & Cukup Baik \\
$0 \% \leq \mathrm{ROA}<0,5 \%$ & Kurang Baik \\
ROA $\leq 0 \%$ & Tidak Baik \\
\hline Sumber: Kodifikasi Penilaian Bank Indonesia
\end{tabular}

Sumber: Kodifikasi Penilaian Bank Indonesia

\section{ROE (Return On Equity)}

Return on Equity, merupakan kemampuan perusahaan dalam menghasilkan laba dengan memanfaatkan modal sendiri yang dimilikinya. ROE dapat dihitung menggunakan rumus matematis sebagai berikut:

$$
R O E=\frac{\text { laba bersih setelah pajak }}{\text { modal inti }} \times 100 \%
$$

\section{Tabel 4}

\section{Kriteria Penilaian ROE}

\begin{tabular}{cc}
\hline Nilai & Predikat \\
\hline ROE $>20 \%$ & Sangat Baik \\
$12,5 \%<\mathrm{ROE} \leq 20 \%$ & Baik \\
$5 \%<\mathrm{ROE} \leq 12,5 \%$ & Cukup Baik \\
$0 \%<\mathrm{ROE} \leq 5 \%$ & Kurang Baik \\
$\mathrm{ROE} \leq 0 \%$ & Tidak Baik \\
\hline
\end{tabular}

Sumber: Surat Edaran Bank Indonesia tahun 2011

4. BOPO/REO (Biaya Operasional Pendapatan Operasional)

BOPO merupakan perbandingan antara biaya operasioanal dengan pendapatan operasional untuk mengukur kemampuan dan efisiensi bank dalam melakukan kegiatan operasinya (Yudiana Febrita Putri, Isti Fadah, 2015). BOPO dapat dihitung menggunakan rumus matematis sebagai berikut:

$$
B O P O(R E O)=\frac{\text { Biaya Operasional }}{\text { Pendapatan Operasional }} \times 100 \%
$$


ISSN Cetak : 2087-0434

E-ISSN : :2599-0810

Tabel 5

Kriteria Penilaian BOPO/ROE

\begin{tabular}{cc}
\hline Nilai & Predikat \\
\hline BOPO $\leq 94 \%$ & Sangat Baik \\
$94 \%<$ BOPO $\leq 95 \%$ & Baik \\
$95 \%<$ BOPO $\leq 96 \%$ & Cukup Baik \\
$96 \%<$ BOPO $\leq 97 \%$ & Kurang Baik \\
BOPO $>97 \%$ & Tidak Baik \\
\hline
\end{tabular}

Sumber: Surat Edaran Bank Indonesia No. 6/23/DPNP Tahun 2004

5. NIM/NOM (Net Interest Margin)

Net Interest Margin, merupakan rasio yang digunakan untuk mengukur kemampuan manajemen bank dalam menghasilkan pendapatan dari bunga dengan melihat kinerja perbankan dalam menyalurkan kredit (Dan et al., 2016). NIM dapat dihitung menggunakan rumus matematis sebagai berikut:

$$
\begin{gathered}
\text { NIM }=\frac{\text { pendapatan bunga bersih }}{\text { total aktiva produktif }} \times 100 \% \\
N O M=\frac{\text { Pendapatan bagi hasil }}{\text { total aktiva produktif }} \times 100 \%
\end{gathered}
$$

Tabel 6

\section{Kriteria Penilaian NIM/NOM}

\begin{tabular}{cc}
\hline Nilai & Predikat \\
\hline NIM $\geq 3 \%$ & Sangat Baik \\
$2 \% \leq \mathrm{NIM}<3 \%$ & Baik \\
$1,5 \% \leq \mathrm{NIM}<2 \%$ & Cukup Baik \\
$1 \% \leq \mathrm{NIM}<1,5 \%$ & Kurang Baik \\
NIM $\leq 1 \%$ & Tidak Baik \\
\hline Sumber: Kodifikasi Penilaian Bank Indonesia
\end{tabular}

\section{LDR/FDR (Loan to Deposit Ratio)}

Loan to Deposit Ratio merupakan rasio yang digunakan untuk mengukur keseimbangan antara dana yang disalurkan dalam bentuk kredit dengan dana dengan dana yang diterima pihak ketiga. LDR dapat dihitung menggunakan rumus matematis sebagai berikut: 
ISSN Cetak : 2087-0434

E-ISSN : $\quad$ 2599-0810

$$
\begin{aligned}
& L D R=\frac{\text { total kredit }}{\text { dana pihak ketiga }} \times 100 \% \\
& F D R=\frac{\text { total pembiayaan }}{\text { dana pihak ketiga }} \times 100 \%
\end{aligned}
$$

Tabel 7

\section{Kriteria Penilaian LDR/FDR}

\begin{tabular}{cc}
\hline Nilai & Predikat \\
\hline $50 \%<$ LDR $\leq 75 \%$ & Sangat Baik \\
$75 \%<$ LDR $\leq 85 \%$ & Baik \\
$85 \%<$ LDR $\leq 100 \%$ & Cukup Baik \\
$100 \%<$ LDR $\leq 110 \%$ & Kurang Baik \\
LDR $\geq 110 \%$ & Tidak Baik \\
\hline
\end{tabular}

Sumber: Surat Edaran Bank Indonesia No. 6/23/DPNP 2004

7. NPL/NPF (Non Perfoming Loan)

Non-Performing Loan, merupakan rasio yang digunakan untuk mengukur kemampuan bank dalam mengcover risiko pengembalian kredit oleh debitur.

NPL dapat dihitung menggunakan rumus matematis sebagai berikut:

$$
\begin{aligned}
& N P L=\frac{\text { Total } N P L(K L, D, M)}{\text { Total kredit }} \times 100 \% \\
& N P F=\frac{\text { Total } N P F(K L, D, M)}{\text { total pembiayaan }} \times 100 \%
\end{aligned}
$$

Tabel 8

\section{Kriteria Penilaian NPL/NPF}

\begin{tabular}{cc}
\hline Nilai & Predikat \\
\hline $\mathrm{NPL} \leq 2 \%$ & Sangat Baik \\
$2 \% \leq \mathrm{NPL}<5 \%$ & Baik \\
$5 \% \leq \mathrm{NPL}<8 \%$ & Cukup Baik \\
$8 \% \leq \mathrm{NPL}<12 \%$ & Kurang Baik \\
$\mathrm{NPL} \geq 12 \%$ & Tidak Baik \\
\hline
\end{tabular}

Sumber: Kodifikasi Penilaian Bank Indonesia

Setelah kriteria setiap rasio ditemukan, selanjutnya setiap kriteria diberi rating kemudian dirata-rata untuk diambil kesimpulan. Peratingan dapat dilihat pada tabel 9. 
ISSN Cetak : 2087-0434

E-ISSN : :2599-0810

Tabel 9

Peratingan Kriteria

\begin{tabular}{cc}
\hline Kriteria & Rating \\
\hline Sangat Baik & 5 \\
Baik & 4 \\
Cukup Baik & 3 \\
Kurang Baik & 2 \\
Tidak Baik & 1 \\
\hline
\end{tabular}

\section{HASIL DAN PEMBAHASAN}

\section{Tabel 10}

Data Rasio Keuangan Perbankan Syariah 2016-2020

\begin{tabular}{|c|c|c|c|c|c|}
\hline Tahı & 2016 & 2017 & 2018 & 2019 & 2020 \\
\hline CAR & 18.96 & 19.67 & 19.93 & 20.82 & 22.86 \\
\hline ROA & 0.91 & 0.97 & 1.02 & 1.1 & 0.97 \\
\hline ROE & 6.19 & 7.45 & 7.64 & 8.33 & 6.79 \\
\hline BOPO & 92.62 & 90.68 & 89.88 & 88.8 & 88.71 \\
\hline NIM/NOM & 3.24 & 3.34 & 3.14 & 3.04 & 2.94 \\
\hline LDR/FDR & 86.22 & 80.05 & 81.75 & 81.34 & 90.21 \\
\hline NPL/NPF & 2.44 & 2.59 & 2.33 & 2.48 & 2.41 \\
\hline
\end{tabular}

Tabel 11

\section{Analisis Statistik Deskriptif}

Descriptive Statistics

\begin{tabular}{|l|l|l|l|l|l|}
\hline & $\mathrm{N}$ & Min & Max & Mean & Std. Deviation \\
\hline CAR & 5 & 18.96 & 22.86 & 20.4480 & 1.50365 \\
ROA & 5 & .91 & 1.10 & .9940 & .07092 \\
ROE & 5 & 6.19 & 8.33 & 7.2800 & .81994 \\
BOPO & 5 & 88.71 & 92.62 & 90.1380 & 1.60858 \\
NIM & 5 & 2.94 & 3.34 & 3.1400 & .15811 \\
LDR & 5 & 80.05 & 90.21 & 83.9140 & 4.21889 \\
NPL & 5 & 2.33 & 2.59 & 2.4500 & .09566 \\
Valid & $N$ & & & & \\
(listwise) & 5 & & & & \\
\hline
\end{tabular}

Sumber: Data diolah kembali 
ISSN Cetak : 2087-0434

E-ISSN : :2599-0810

Berdasarkan tabel 11. tentang hasil analisis deskriptif dari keseluruhan rasio perbankan syariah yang diteliti dengan tolok ukur rasio-rasio keuanga terkait maka kinerja perbankan syariah yang terdaftar di Otoritas Jasa Keuangan dapat dijabarkan sebagai berikut:

1) Nilai Capital Adequacy Ratio (CAR) paling rendah adalah $18,96 \%$ dan nilai CAR paling tinggi adalah 22,86\% dengan rata-rata nilai CAR sebesar 20,4428\%. Nilai CAR terendah terjadi pada tahun 2016 dan nilai CAR tertinggi terjadi di tahun 2020. Berdasarkan kriteria penilaian Bank Indonesia terhadap kinerja bank maka dari tahun 2016 hingga tahun 2020 perbankan syariah terdaftar di OJK dalam aspek permodalan yaitu kecukupan modal bank dalam mendukung kegiatan bank secara efisien dinilai sangat baik karea nilai CAR lebih dari sama dengan $12 \%$. Standar deviasi pada data CAR sebesar 1,50365 menunjukkan simpangan data yang relatif kecil karena nilainya lebih kecil dari nilai mean yang sebesar 20,4480. Hal tersebut menunjukkan data sampling CAR bagus dan cukup mewakili populasi yang sedang diteliti.

2) Return on Asset (ROA) paling rendah adalah $0,91 \%$ yang terjadi pada tahun 2016 dan nilai ROA paling tinggi adalah 1,1\% yang terjadi di tahun 2019. Berdasarkan kriteria penilaian Bank Indonesia terhadap kinerja bank maka kemampuan bank syariah dalam menghasilkan laba dengan memanfaatkan seluruh modal dari tahun 2016 hingga tahun 2020 dinilai cukup baik karena nilai ROA lebih dari sama dengan $0,5 \%$ dan kurang dari $1,25 \%$. Standar deviasi sebesar 0.07092 menunjukkan simpangan data yang ralatif kecil dan data ROA cukup mewakili populasi bank syariah yang diteliti karena nilai mean lebih besar yaitu sebsar 0.9940 .

3) Return on Equity (ROE) paling rendah adalah 6, 19\% yang terjadi pada tahun 2016 dan nilai ROE tertinggi adalah 8, 33\% yang terjadi di tahun 2019. Berdasarkan kriteria penilaian Bank Indonesia terhadap kinerja bank maka bank syariah kemampuan bank syariah dalam menghasilkan laba dengan memanfaatkan modal sendiri dari tahun 2016 hingga tahun 2020 dinilai cukup baik karena nilai ROE lebih dari 5\% dan kurang dari sama dengan $12,5 \%$. Standar deviasi sebesar 0.81994 menunjukkan simpangan data yang 
ISSN Cetak : 2087-0434

E-ISSN : :2599-0810

relatif kecil dan data ROE yang digunakan mewakili populasi bank syariah yang diteliti karena nilai mean lebih besar dari standar deviasi yaitu sebesar 7.28 .

4) Biaya Operasional Pendapatan Operasional (BOPO) paling rendah adalah 88,71\% yang terjadi pada tahun 2020 dan nilai BOPO tertinggi adalah 92,62\% yang terjadi di tahun 2016. Berdasarkan kriteria penilaian Bank Indonesia maka tingkat efisiensi dan kemampuan bank dalam melakukan kegiatan operasinya dinilai sangat baik karena nilai BOPO kurang dari sam dengan 94\%. Standar deviasi sebesar 1.60858 menunjukkan simpangan data yang relative kecil dan data BOPO dianggap mewakili populasi karena nilai mean lebih besar dari standar deviasi yaitu sebsar 90.1380.

5) Net Interest Margin (NIM) paling rendah adalah sebesar 2, 94\% yang terjadi pada tahun 2020 dan NIM paling tinggi terjadi pada tahun 2017 yaitu sebesar 3, 34\%. Berdasarkan kriteria penilaian Bank Indonesia maka kemampuan manajemen bank dalam menghasilkan pendapatan dari bunga dinilai baik karena NIM lebih dari sama dengan 2\% kurang dari 3\% dan dinilai sangat baik juga karena lebih dari 3\% untuk nilai NIM tertinggi. Jika dilihat dari mean sebesar 3,14\% maka NIM pada bank syariah terdaftar di OJK dinilai sangat baik. Standar deviasi sebesar 0, 15811 menunjukkan simpangan data relatif kecil dan data NIM dianggap mewakili populasi karena nilai mean lebih besar yaitu sebesar 3, 14 .

6) Loan to Deposite (LDR) paling rendah adalah $80,05 \%$ yang terjadi pada tahun 2017 dan LDR tertinggi terjadi pada tahun 2020 yaitu sebesar 90,21\%. Berdasarkan kriteria penilaian Bank Indonesia maka kemampuan bank dalam keseimbangan antara dana yang disalurkan dalam bentuk kredit dengan dana yang diterima pihak ketiga dari tahun 2016 hingga tahun 2020 dinilai cukup baik. Standar deviasi sebesar 4.21889 menunjukkan simpangan data yang relative kecil dan data LD R dianggap mewakili populasi yang diteliti karena nilai mean lebih besar dari standar deviasi yaitu sebesar 83.9140.

7) Non-Performing Loan (NPL) paling rendah adalah 2,33\% yang terjadi pada tahun 2018 dan NPL paling tinggi terjadi pada tahun 2017 yaitu sebesar 2,59\%. Berdasarkan kriteria penilaian Bank Indonesia maka kemampuan 
ISSN Cetak : 2087-0434

E-ISSN : $\quad$ 2599-0810

bank dalam mengcover risiko pengembalian kredit oleh debitur dari tahun 2016 hingga tahun 2020 dinilai baik karena nilai NIM lebih besar sama dengan 2\% dan kurang sari 5\%. Standar deviasi sebesar 0.09566 menunjukka simpangan data yang relative kecil dan data NPL dianggap mewakili populasi yang diteliti karena nilai mean lebih besar dari nilai standar deviasi yaitu sebesar 2, 45 .

Tabel 12

Hasil Peratingan

\begin{tabular}{lc}
\hline \multicolumn{1}{c}{ Rasio } & Rating \\
\hline Capital Adequacy Ratio (CAR) & 5 \\
Return On Asset (ROA) & 3 \\
Return On Equity (ROE) & 3 \\
Biaya Operasional Pendapatan Operasional (BOPO) & 5 \\
Net Interest Margin (NIM) & 4 \\
Loan to Deposite (LDR) & 3 \\
Non Performing Loan (NPL) & 4 \\
Nilai Rata-Rata & $\mathbf{3 , 8 6}$ \\
\hline
\end{tabular}

Berdasarkan tabel 12 tentang hasil peratingan diperoleh nilai rata-rata rating sebesar 3,86 atau dibulatkan menjadi 4 maka kinerja bank syariah terdaftar di OJK periode 2016-2020 dinyatakan Baik. Jika kita lihat berdasarkan tabel 10. yang menguraikan data rasio keuangan secara lengkap dari tahun 2016-2020 maka selama periode berjalan kinerja bank umum syariah di Indonesia tidak mengalami perubahan yang berarti. Artinya selama periode lima tahun terakhir tetap mampu menjaga kinerjanya tetap baik. Namun, jika kita lihat kembali kinerja paling buruk selama periode yang diteliti adalah pada tahun 2020. Hal tersebut dimungkinkan terjadi karena berbagai faktor yang menyebabkan sentimen negatif terhadap perekonomian di Indonesia yang berimbas terhadap bank umum syariah.

\section{KESIMPULAN}

Berdasarkan hasil dan pembahasan dapat disimpulkan bahwa perbankan syariah yang terdaftar di OJK periode 2016-2020 memiliki kinerja keuangan yang baik. Hal tersebut dapat dibuktikan dari hasil peratingan yang menunjukkan kinerja bank syariah yang diteliti secara keseluruhan memperoleh nilai rata-rata sebesar 3,86 atau dibulatkan menjadi 4 sehingga kinerja bank syariah yang terdaftar di OJK periode 2016-2020 dianggap baik. Selain itu, berdasarkan kriteria penilaian Bank 
ISSN Cetak : 2087-0434

E-ISSN : $\quad$ 2599-0810

Indonesia terhadap kinerja bank setiap rasio menunjukkan kinerja yang sangat baik, baik, dan cukup baik. Hasil analisis data setiap rasio yang dianalisis menunjukkan nilai standar deviasi yang lebih kecil dari nilai mean atau rata-ratanya. Hal tersebut menunjukkan bahwa simpangan data yang digunakan relatif kecil, sehingga data yang digunakan dianggap mampu mewakili keseluruhan populasi perbankan syariah yang diteliti. Hasil penelitian yang menunjukkan bahwa kinerja perbankan syariah terdaftar di OJK baik dapat memberikan gambaran kepada masyarakat, investor, dan debitur untuk mempertimbangkan bank syariah sebagai tempat mereka melakukan penyetoran, deposito, dan peminjaman dana. Sistem bagi hasil yang diterapkan oleh bank syariah juga memungkinkan adanya pembagian hasil dan resiko yang sama rata antara pihak bank dengan nasabah. Nasabah tidak dirugikan dan bebas dari riba.

Penelitian ini hanya menggunakan tujuh rasio keuangan yang dianggap penting dalam menilai kinerja suatu bank. Rasio-rasio tersebut yaitu, Capital Adequacy Ratio (CAR), Return On Asset (ROA), Return On Equity (ROE), Biaya Operasional Pendapatan Operasional (BOPO), Net Interest Margin (NIM), Loan to Deposite (LDR), dan Non Performing Loan (NPL). Penelitian ini tidak melibatkan analisis Risk Profile dan Good Corporate Governance dalam menilai kinerja perbankan syariah. Diharapkan penelitian-penelitian selanjutnya yang serupa juga menggunakan analisis Risk Profile dan Good Corporate Governance dalam melakukan penelitian agar hasil yang didapatkan lebih mempertimbangkan banyak aspek.

\section{DAFTAR REFERENSI}

Aziz, N. (2017). Analisis Intermediasi bank Syariah vs Bank Konvensional Dalam Dual Banking System (Studi Kasus Indonesia)”. http://repository.ub.ac.id/id/eprint/109587

Dan, K., Syariah, B., Ayu, G., \& Purnamasari, Y. (2016). ISSN: 2302-8556 E-Jurnal Akuntansi Universitas Udayana Fakultas Ekonomi dan Bisnis Universitas Udayana ( Unud ), Bali, Indonesia Perbankan merupakan lembaga keuangan yang memiliki peranan keuangan yang cukup penting di Indonesia . Ini disebabkan karena . 15, 82110.

Dr. Gendro Wiyono, S.I.P., M.M dan Prof. Dr. Drs. Hadri Kusuma, M.BA., D. B. (2017). Manajemen Keuanga Lanjutan (Pertama). UPP STIM YKPN.

Husain, M. R., \& Hikmah, N. (2018). Penilaian Tingkat Kesehatan Bank Syariah Mandiri : Pendekatan Metode Rgec ( Risk Profile, Good Corporate Governance, Earning Dan 
ISSN Cetak : 2087-0434

E-ISSN : :2599-0810

Capital ). 2(1), 69-80.

Indonesia, D. I. (2014). Efisiensi perbankan syariah di indonesia. $7(2)$. https://doi.org/10.15294/jejak.v7i1.3596

Orniati, Y. (2009). Laporan Keuangan sebagai Alat untuk Menilai Kinerja Keuangan.

Prihatin, K. S., \& Anjani, S. (2021). Analisis Pengukuran Tingkat Kesehatan Perbankan Syariah Dengan Menggunakan Metode Camel Pada Pt. Bank Mandiri Syariah Tbk. Progress: Jurnal Pendidikan, Akuntansi Dan Keuangan, 4(1), 17-37. https://doi.org/10.47080/progress.v4i1.1124

Rama, A. (2013). Perbankan Syariah Dan Pertumbuhan Ekonomi Indonesia. Signifikan: Jurnal Ilmu Ekonomi, 2(1), 33-56. https://doi.org/10.15408/sjie.v2i1.2372

Sovia, S. E., Saifi, M., \& Husaini, A. (2016). Analisis Perbandingan Kinerja Keuangan Bank Konvensional Dan Bank Syariah Berdasarkan Rasio Keuangan Bank. Jurnal Administrasi Bisnis, 37(1), 129-136. https://media.neliti.com/media/publications/87164-ID-analisis-perbandingan-kinerjakeuangan-b.pdf

Thayib, B., Murni, S., \& Joubert.B.Maramis. (2017). ANALISIS PERBANDINGAN KINERJA KEUANGAN BANK SYARIAH DAN BANK KONVENSIONAL. EMBA, 5 .

Vivin, Y. A., \& Wahono, B. (2017). Analisis Perbandingan Kinerja Keuangan Bank Umum Syariah dengan Bank Umum Konvensional di Indonesia. E-Jurnal Riset Manajemen, 77-97.

Yudiana Febrita Putri, Isti Fadah, D. T. E. (2015). Analisis Perbandingan Kinerja Keuangan Bank Konvensional Dan Bank Syariah. JEAM, XIV. 